\title{
Frásögn Ibn Fadlan af víkingum við Volgubakka árið $922^{1}$
}

\begin{abstract}
Pegar frásögnin hefst hefur Ibn Fadlan dvalið í ríki Volgu-Búlgara um nokkurt skeið. Fram að pessu hefur ferðasagan verið nokkuð línuleg og yfirveguð en pað er augljóst að kynni hans af víkingunum hrista verulega upp í heimsmynd hans.
\end{abstract}

Ég sá Rús ${ }^{2}$ sem voru komnir til að stunda viðskipti og lögðu festar við bakka árinnar Itil. ${ }^{3}$ Ég hef aldrei séð pvílíkt atgervi. Deir eru hávaxnir eins og pálmatré, ljósir yfirlitum og rjóđir. Peir klæðast hvorki kyrtli né serk. Hver maður hylur helming efri líkama síns með slá, pannig að önnur höndin er laus og liðug. Peir bera axir, sverð og kuta og hafa pá alltaf innan handar. Peir nota frankísk sverð með breiðum blöðum. Peir eru alpaktir dökkum myndum frá toppi til táar: dökkum útlínum af trjám og annars konar myndum. ${ }^{4}$

Sérhver kona meðal peirra ber framan á sér litla öskju úr járni, silfri, messing, eða gulli, allt eftir fjárhag og stöðu eiginmanns síns. Úr öskjunni hangir hringur og í honum lítill hnífur fram á brjóstið.

Um hálsinn bera pær hringi úr gulli og silfri. Pegar eiginmaðurinn hefur eignast tíu púsund dirhama [arabísk silfurmynt] lætur hann gera hálshring fyrir konu sína og pegar hann hefur eignast

1 Pýtt eftir útgáfu arabíska handritsins í Mission to the Volga, ritstj. og pýd. J. E. Montgomery, New York: New York University Press, 2014, bls. 198.

2 Rús (arabíska ar-Rus) er heitið sem arabískir höfundar nota venjulega um norræna menn eða víkinga í austurvegi.

3 Itil (eða Atil) er túrkíska heitið á ánni Volgu. Arabískir höfundar notuðu pað einnig um ána.

4 Petta er óvenjuleg vísun í notkun húðflúra meðal víkinga sem ekki hefur fundist í öðrum heimildum. 
tuttugu púsund lætur hann gera tvo og pannig lætur hann gera hring handa konu sinni fyrir hverja tíu púsund dirhama <sem hann eignast $>$. Sumar hafa marga hringi um hálsinn.

Pað skart sem peir halda mest upp á eru grænar perlur úr postulíni/leir sem peir hafa á skipum sínum. Peir prútta og kaupa perlurnar á einn dirham < hverja > og præða pær í hálsmen handa konum sínum.

Peir eru skítugastir af öllum peim sem Allah hefur skapað. Peir blygðast sín hvorki fyrir að hafa hægðir né pvaglát á almannafæri, prífa sig ekki eftir samfarir og pvo ekki hendur sínar eftir að hafa matast. Peir eru sannarlega eins og ráfandi asnar!

Deir ferðast frá lendum sínum, leggja skipunum á ánni Itil, sem er mikið fljót, og reisa stór timburhús á bökkum hennar. Deir safnast saman tíu eða tuttugu í einu húsi, <stundum> færri og $<$ stundum > fleiri. Hver og einn hefur bedda sem hann situr á og með peim eru fallegar ambáttir sem peir hyggjast selja. Deir hafa mök við pær á meðan félagar peirra horfa á og stundum gera peir petta margir saman í einum hóp.

Pað kemur fyrir að kaupmaður heimsækir pá til að kaupa ambátt á meðan eigandinn hefur samfarir við hana og hættir ekki fyrr en hann hefur svalað pörf sinni.

Á degi hverjum pvo peir andlit sitt og höfuð upp úr grútskítugu vatni. Á morgnana færir ambátt eiganda sínum skál fulla af vatni. Hann pvær hendur sínar, andlit og hár og strýkur greiðu gegnum hárið ofan í vatnið. Pví næst snýtir hann sér og hrækir í skálina. Hann óhreinkar petta vatn á allan mögulegan máta. Pegar hann hefur lokið sér af, ber ambáttin skálina til sessunautar hans, sem gerir eins og félagi sinn. Svo flytur hún skálina til næsta manns, og pannig koll af kolli til allra í húsinu. Allir snýta peir sér og hrækja í skálina, og pvo andlit sitt og hár.

peir ganga á land um leið og peir hafa lokið við að festa báta sína. Hver og einn hefur meðferðis brauð, kjöt, lauk, mjólk og brennivín, ${ }^{5}$ sem peir leggja hjá viðarsúlu sem peir hafa reist. Á henni er <útskorið> andlit sem líkist mannsandliti og umhverfis súluna eru litlar myndir og líkneski úr tré sem hefur verið stungið í jörðina.

5 Arabíska orðið hér er nabidh. Pað getur merkt ýmiskonar vín, hugsanlega er hér um að ræða mjöð. 
Hver maður krýpur fyrir framan líkneskið og segir: „Herra! Ég er kominn langt að og hef með mér svo og svo margar ambáttir og svo og svo mörg skinn“. Pannig pylur hann upp allan varninginn og segir svo: „Ég hef fært pér pessa fórn“. Hann leggur fórnina sem hann kom með hjá viðarsúlunni og segir: „Blessaðu mig og færðu mér ríkan kaupmann með marga dínara [arabísk gullmynt] og dirhama, sem kaupir af mér pað sem ég vil og prúttar ekki um pað verð sem ég set upp“. Að pví búnu snýr hann til baka.

Ef erfitt reynist að selja varninginn kemur hann aftur með aðra fórn og svo pá priðju. Ef ekkert gengur færir hann öllum litlu líkneskjunum gjafir og biður bau að hjálpa til og segir: „Detta eru konur, dætur og synir Herrans okkar“. Svo krýpur hann og biður hvert líkneski fyrir sig um aðstoð.

Stundum gengur salan hratt og vel fyrir sig og pá segja peir: „Herra minn hefur orðið við óskum mínum og nú parf ég að endurgjalda honum“. Hann safnar pá saman nokkrum kindum og kúm og slátrar. Hluta kjötsins gefur hann hinum purfandi en afganginn leggur hann við stóra líkneskið og hin minni par í kring. Dví næst bindur hann hausana af fénaðinum á viðarsúlurnar. Pegar nóttin skellur á koma hundar og éta petta allt saman og pá segja peir: „Herrann gladdist yfir pví sem ég gerði og neytti fórna minna“.

Ef einhver peirra veikist slá peir upp tjaldi fyrir hann afsíðis, leggja hann í pað og með honum nokkuð af brauði og vatni. Peir hvorki koma nálægt honum né tala við hann og sinna honum í engu á meðan hann er sjúkur, sérstaklega ef hann er vesalingur eða præll. Ef honum batnar og hann kemst á fæur fer hann aftur til manna sinna en ef hann deyr er hann skilinn pannig eftir og hundar og ránfuglar éta hann. Ef peir klófesta pjóf eða glæpamann hengja peir hann upp í burðugt tré og setja sterkt snæri um háls hans. Par hangir hann par til vindurinn og regnið tortíma honum.

Mér barst til eyrna að mikilvægur maður úr peirra röðum hefði dáið. Deir höfðu sett hann í gröf og reist skýli par yfir. Par lá hann í tíu daga par til búið var að sníða klæði hans og sauma. Ef hinn látni er fátækur maður smíđa peir lítinn bát sem peir leggja hann í og brenna. Ef hann er ríkur maður skipta peir auði hans í prennt: einn priðji gengur til heimilisfólks hans, einum priðja er varið ílíkklæðin, og einum priðja í að brugga drykk pann sem drukkinn er 
pegar ambátt fórnar sér og er brennd ásamt eiganda sínum. Deir drekka vín og peir drekka nótt og dag, stundum deyr einn af peim með bikar í hendi.

Pegar höfðingi deyr spyr heimilisfólk hans ambáttir hans og præla hver vilji deyja með honum. Einhver peirra segir: „Ég“. Pessi yfirlýsing er bindandi og pað er ekki hægt að snúa ákvörðuninni við. Yfirleitt eru pað ambáttirnar sem bjóða sig fram.

Degar sá sem ég hef pegar getið dó voru ambáttir hans spurðar hver peirra vildi deyja með honum og ein peirra sagði „ég“. Dví næst var hún sett í umsjá tveggja annarra ambátta sem pjónuðu henni og fylgdu henni eftir hvert fótmál og pvoðu jafnvel fæur hennar með höndum sínum. Svo voru klæði höfðingjans skorin til og öðrum undirbúningi sinnt. Ambáttin drakk nabidh og söng glöð og kát dag hvern.

Daginn sem átti að brenna höfðingjann og ambáttina fór ég niður að ánni og sá skip hans. Búið var að draga pað upp á land og við pað studdu fjórir stöplar úr khadank-tré6 og umhverfis pá var stærðar timburgrind. Skipið hafði verið dregið upp á pessa grind.

Rús-fólkið færði sig nær og gekk svo fram og til baka og í kringum skipið og mælti orð sem ég skildi ekki. Höfðinginn var enn pá í gröf sinni og hafði ekki verið grafinn upp. Fólkið útbjó fleti á skipinu og breiddi yfir pað teppi og svæfla úr býsönsku silki. Nú birtist öldruð kona sem peir kölluðu Engil Dauðans. ${ }^{7}$ Pað var hún sem útbjó fletið sem við höfum nefnt. Hún sér um að sauma líkklæði höfðingjans og útbúa hann á réttan hátt og pað er hún sem líflætur ambáttirnar. Ég sá hana: Hún var á óræðum aldri, stór, dökk yfirlitum og drungaleg.

Fólkið fór að gröf hans [höfðingjans]; pau mokuðu moldinni frá, fjarlægðu timbrið og grófu hann upp, klæddan í pau föt sem hann var í pegar hann lést. Ég tók eftir að líkami hans var orðinn svartur vegna kuldans á pessum slóðum. ${ }^{8}$ Nabidh, ávextir og strengjahljóðfæri ${ }^{9}$ höfðu verið sett í gröfina með honum og fólkið fjarlægði petta

6 Líklega birki eða ösp.

7 Arabíska hugtakið hér er malak al-mawt (orðrétt „engill dauðans“), sem kemur víða fyrir í Kóraninum. Ekki er ljóst hvort Ibn Fadlan er hér að pýða orðið eða nota íslamska hugtakið í stað einhvers annars.

8 Ibn Fadlan kemur til ríkis Volgu-Búlgara að vori. Vísun hans í kulda bendir mögulega til pess að hann hafi dvalið um alllangt skeið meðal peirra og parna sé farið að hausta eða vetra aftur.

9 Arabíska orðið hér er tanbur, sem mögulega er einhvers konar lúta. 
allt saman. Hann var ekki farinn að lykta illa og ekkert hafði breyst á honum nema litaraftið. Hann var pví næst klæddur í buxur, legghlífar, skó, kyrtil og silkiserk með gullhnöppum. Á höfuð hans var sett silkihúfa með loðfeldi. Fólkið bar hann inn í tjaldið sem hafði verið reist á skipinu, lagði hann á fletið og notaði svæflana til að halda honum uppréttum. Pað setti hjá honum nabidh, ávexti og basil, ${ }^{10}$ og pví næst brauð, kjöt og lauka fyrir framan hann. Pá var hundur klofinn í tvennt og honum hent á skipið. Tveir hestar voru látnir hlaupa par til svitinn spratt út á peim, síðan voru peir klofnir í tvennt með sverði og hent á skipið. Tvær kýr voru hoggnar niður og peim hent á skipið. Pví næst voru hani og hæna drepin og sett um borð.

Á meðan gekk ambáttin sem hafði ákveðið að fórna sér fram og til baka og fór inn í hvert tjaldið á fæutur öðru. Eigandi hvers tjalds hafði mök við hana og sagði: „Segðu eiganda pínum að ég hafi gert petta vegna ástar pinnar á honum“.

Um sî̉degisbil á föstudeginum leiddu nokkrir menn ambáttina að hlut sem peir höfðu smíðað og líktist dyrastöfum. Hún stóð á höndum mannanna, var lyft yfir dyrastafinn og mælti einhver orð. Pví næst létu peir hana síga og lyftu henni aftur og hún gerði eins og í fyrra skiptið. Peir létu hana síga og rísa í priðja skiptið og hún gerði pað sama og í fyrri tvö skiptin. Pá réttu peir henni hænu, hún hjó hausinn af henni og kastaði frá sér. Peir tóku hænuna og köstuðu henni á skipið. Ég spurði túlkinn út í gjörðir hennar og hann svaraði:

Í fyrsta skiptið sem peir lyftu henni sagði hún: „Sjá! Ég sé föður minn og móður mína. Í annað skiptið <sagði hún>: „Sjá! Allir framliðnir ættingjar mínir í samsæti“ og í priðja skiptið: „Sjá! parna situr eigandi minn í Garðinum ${ }^{11}$ og Garðurinn er grænn og fagur. Hann er með mönnum sínum og prælum. Hann kallar til mín að koma og segir farðu til hans!"12

peir fóru með hana að skipinu og hún tók af sér tvö armbönd sem hún bar og afhenti pau konunni sem kölluð var Engill Dauðans,

10 Arabíska orðið hér er rayhan, sem er sætt basil. Mögulega var pað notað til að verja líkið rotnun meðan pað var geymt í bráðabirgðagröfinni.

11 Arabíska orðið hér er jannah, sem kemur alloft fyrir í Kóraninum og merkir paradís.

12 Mögulega er hér einhver ruglingur í handritinu og pað sem átt er við er að einhver aðstoðarmannanna sé að hvetja prælastúlkuna með pví að segja: „Farðu til hans!“ 
peirri sem myndi drepa hana. Hún tók einnig af sér tvö ökklabönd og rétti ambáttunum tveim sem höfðu pjónað henni, <en pær eru> dætur konunnar sem pekkt er sem Engill Dauðans.

Mennirnir lyftu henni upp á skipið en færðu hana ekki inn í tjaldið. Peir komu að með skildi og prik og færðu henni bikar með nabidh. Hún söng yfir drykknum og drakk hann. Túlkurinn sagði mér að nú væri hún að kveðja hinar ambáttirnar. Henni var réttur annar bikar og hún söng lengi yfir honum. Kerlingin hvatti hana til að drekka og fara svo inn í tjaldið par sem eigandi hennar lá. Ég sá að hún var orðin ringluð. Hún reyndi að komast inn í tjaldið en tókst bað ekki. Hún setti höfuðið til hliðar við tjaldið, á milli pess og borðstokksins. Kerlingin tók pá í höfuð hennar og fór inn í tjaldið með henni. Mennirnir tóku að berja skildi sína með prikunum svo öskrin í henni myndu ekki heyrast. Pað myndi hræða hinar ambáttirnar sem myndu pá ekki bjóðast til að deyja með eiganda sínum.

Sex menn fóru inn í tjaldið. Deir höfðu allir mök við ambáttina og lögðu hana við hlið eiganda hennar. Tveir héldu um fæur hennar og tveir um hendur hennar. Kerlingin, sem kölluð er Engill Dauðans, lagði reipi um háls hennar pannig að endarnir lágu sitt hvorum megin < við hana $>$ og rétti pá tveimur mönnum til að toga í. Hún færði sig nær með breiðan rýting og rak hann á milli rifbeina hennar, hér og par, á meðan mennirnir tveir kyrktu hana með reipinu par til hún dó.

Að pví loknu kom nánasti ættingi hins látna, tók upp kyndil og kveikti í. Hann var allsnakinn, gekk aftur á bak og sneri hnakkanum að skipinu. Hann hélt á kyndlinum í annarri hendi en með hinni hélt hann fyrir endaparminn. Hann lagði eld að grindinni undir bátnum. Pá kom fólk að með spýtur og eldivið. Allir héldu á logandi kyndli sem peir hentu svo á bálköstinn. Eldurinn magnaðist, logarnir gleyptu skipið, svo tjaldið, höfðingjann og ambáttina og allt annað sem var um borð. Pá kom öflug vindhviða, logarnir hækkuðu og hækkuðu og æddu um.

Einn af Rús-mönnunum stóð við hliðina á mér. Ég heyrði hann tala við túlkinn sem var með mér. Ég spurði hvað hann hafði sagt og < túlkurinn> sagði: „Dið arabísku kumpánar eruð fávísir!“

„Hví pá pað?“ 
„Pið takið hina elskuðu og hina tignu á meðal ykkar og fleygið peim í jörðina, og skordýrin og ormarnir éta pá. Við < hins vegar > brennum pá samstundis og peir komast strax inn í Garðinn.“ Ég spurði hann út í petta og hann sagði: „Herrann elskar hann svo að hann sendir vind til að taka hann á einni klukkustund“. Og í raun og sann tók pað aðeins klukkustund fyrir skipið, eldiviðinn, ambáttina og eiganda hennar að brenna til ösku og svo að fínni ösku. Rús-fólkið reisti pví næst eitthvað sem líktist lítilli hringlaga hæð yfir skipið sem peir höfou <áður> dregið á land og settu par á miðja hæðina stórt viðarspjald par sem peir skrifuðu nafn mannsins og nafn konungs peirra. Að pví loknu héldu peir á brott.

Eftirfarandi brot er úr verki Yaqut Al-Hamawi, ${ }^{13}$ sem getið er að ofan, og er pessa lýsingu ekki að finna hjá Ibn Fadlan:

< Ibn Fadlan> sagði: Рað er siður konungs Rús að hafa fjögur hundruð af sínum hugrökkustu mönnum og peim sem hann treystir best með sér í höll sinni. Peir deyja pegar hann deyr og fórna lífi sínu til að vernda hann. Hver og einn peirra hefur ambátt sem pjónar honum, pvær höfuð hans og gefur honum að borða og drekka og aðra til að hafa mök við ... Og pessir fjögur hundruð sitja við fleti konungsins sem er grîđarstórt og alsett gimsteinum. Fjörutíu ambáttir sitja með honum á fletinu. Stundum hefur hann mök við eina peirra fyrir framan félaga sína. Hann stígur aldrei úr fleti sínu. Pegar hann parf að ganga örna sinna gerir hann pað í bakka. Pegar hann vill ríða út er hestur færður að hásætinu og hann stígur á bak honum af pví. Pegar hann vill fara af baki ríður hann að hásætinu og fer af baki par. Hann hefur fulltrúa sem leiðir heri hans, berst við óvini og talar máli hans meðal pegnanna.

\section{pórir Jónsson Hraundal pýddi úr arabísku}

13 Mission to the Volga, bls. 252. 